\title{
Grundtvig Partnership Case Study 2009-2011 LifeLong Learning for Active Citizenship and Capacity Building LLLab
}

\author{
Anna Grabowska \\ PRO-MED sp. z o.o., Dolne Migowo 16 C, \\ 80-952 Gdańsk, Poland
}

\begin{abstract}
Lifelong Learning (LLL) is the key concept of European Union (EU) and European Commission (EC) recommends Promoting Access and Participation in Lifelong Learning for All starting with 1996 European year of LLL and continuing with Feira (2000) and Lisbon (2000) European Council proceedings. With these principles in mind, the project Lifelong Learning for Active Citizenship and Capacity Building (LLLab) sets out to make the knowledge triangle (education, research and innovation) accessible to employed people to promote the concept to wider audiences and to build capacity of the employed in order for them to better respond to the new challenges of the EU standards in a developing intercultural knowledge-based society. LLLab is aimed to develop a culture of learning in the partner organizations to obtain a rise in skills levels, better employability, social inclusion, active citizenship and personal development which in the end will inevitably mean sustainable development of the European society.
\end{abstract}

Keywords: Lifelong Learning, e-learning, blended learning, U3A Online.

\section{Introducing Lifelong Learning Program Grundtvig}

The Grundtvig programme [1] focuses on the teaching and study needs of those in adult education and alternative education streams, as well as the institutions and organisations delivering these services. Supporting lifelong learning and mobility in this way also tackles Europe's ageing population problem.

Launched in 2000 and now part of the overarching Lifelong Learning Programme, Grundtvig aims to provide adults with ways to improve their knowledge and skills, keeping them mentally fit and potentially more employable.

It not only covers learners in adult education, but also the teachers, trainers, education staff and facilities that provide these services. These include relevant associations, counseling organisations, information services, policy-making bodies and others involved in lifelong learning and adult education at local, regional and national levels, such as NGOs, enterprises, voluntary groups and research centres.

At least $55 \%$ of the total funding for Grundtvig should go towards mobility and partnership activities. 
Specific aims of the Grundtvig program are the following:

- Increase the number of people in adult education to 25000 by 2013 , and improve the quality of their experience, whether at home or abroad

- Improve conditions for mobility so that at least 7000 people per year by 2013 can benefit from adult education abroad

- Improve the quality and amount of co-operation between adult education organisations

- Develop innovative adult education and management practices, and encourage widespread application

- Ensure that people on the margins of society have access to adult education, especially older people and those who left education without basic qualifications

- Support innovative ICT-based educational content, services and practices

\section{Introducing LifeLong Learning for Active Citizenship and Capacity Building - LLLab Project}

LLLab project supports the better access and better implementation of LLL program in the organizations involved, empowers them and builds their social capital as well. LLLab incorporates the concepts of creativity and innovation in its activities since capacity for these concepts have their roots in cultural and interpersonal skills, values and the competencies in the European reference framework that can be gained only through education.

The objectives of the project partnership are the following:

- to promote the vision for LLL in partner countries, to educate the staff about its aims, outcomes and the background;

- to promote access and increase participation in LLL for the staff and clients of the partner organizations;

- to broaden access to LLL opportunities and innovative expressions;

- to promote flexible education and training methods and approaches to create a culture of learning;

- to create learning opportunities, seminars, workshops for the employees/members of partner organizations by the help of the identified practises and activities derived from these;

- to improve the quality and accessibility of mobility in adult education by increasing the volume of cooperation and to significantly improve the degree of involvement within the learning process and also the evaluation criteria;

- to visibly increase the investment in human resources in order to turn to good account most of the human potential; to make sure that everyone gets easy and permanent access to quality information and advice about what they want to learn in the country and in Europe;

- to develop capacity and institution building by developing LLL skills in general, basic competencies and critical thinking derived from knowledge based society to adjust them to the continuous change in the society and in their work;

- to support innovative and creative expressions at work and in the community;

- to facilitate personal growth and as result of it the social cohesion; 
- to create a multinational and intercultural environment and promote intercultural dialogue;

- $\quad$ to provide motivation and foster language learning;

- to increase productivity at work and personal fulfillment both at work and in the community by developing skills, competencies and knowledge within personal, civic, social and employment perspectives.

\section{Introducing Project Partnership}

The project Partnership consists of 5 institution from 5 different European countries:

Coordinator: Bolu Valiliği, İzzet Baysal Cad. Merkez 14100 Bolu-Türkiye, Turkey

URL: http://www.bolu.gov.tr/

e-mail: boluvalilikpb@gmail.com

Governorship of Bolu is the centre of provincial administration and the representative of the government and each ministry including the Ministry of Education. Being in the pre-accession period, Turkey is expected to follow up with the EU standards in its institutions and capacity and institution building are essential for the government staff. For better social cohesion, the organization should take part in intercultural activities that will strengthen the internalization of EU decisions and cross-border cooperation. For a changing world, they want to prepare their staff and their clients by making lifelong learning a reality in the EU context.

Partner 1: Avalon, Initiatives per a les associations, Ronda Universitat 31, 5-2, 08007, Barcelona, Spain

URL: http://www.avalon.cat/

e-mail: avalon@avalon.catis

The Avalon association was born in 2001 in order to give support and strengthen little, middle and new born organizations in the Catalan associative net. Avalon's tasks are the following: advising and guiding organizations through their evolution and growth, educating, through associative management courses such as Fundraising, Project Management, Internal Communication and Team Work, New channels of Communication (ICT), etc., informing, through articles, documentation, publications, bibliography, links, etc, hanging from a webpage; and exchanging information through a forum created specifically to exchange information about all these subjects. Avalon target is the overall people involved in the non-profit sector. However, they have some programs and courses specifically addressed to the following communities: Immigrant Organizations, People with Special Needs Organizations, and Development and Cooperation Organizations.

Partner 2: Karpatská nadácia Slovensko- Carpathian Foundation Slovakia, Letná 27, 040 01, Košice, Eastern Slovakia, Slovakia

URL: http://www.karpatskanadacia.sk/, http://www.carpathianfoundation.org/, e-mail: cfsk@cfoundation.org

The Carpathian Foundation was founded in 1994 by the East - West Institute, with generous financial support of the Charles Stewart Mott Foundation. The Foundation was created to serve as an active and unique cross - border grant maker in the 
Carpathian region. The core activities are grant programs and scholarship programs. The Foundation makes grants to support nonprofit organizations, individuals and local governments in a variety of areas. To its grantees, the Foundation provides financial support, expert advisory services, training and technical assistance to local communities in order to facilitate development of networks, partnerships and collaboration in the region. The Foundation focuses on supporting multi-cultural and inter-ethnic communities, building cross-sector partnerships and public engagement. Within several of its programs, the Foundation has provided series of trainings for different target groups, such as nonprofit organizations, Roma etc. Also, the Foundation promotes the topics of corporate social responsibility and inter-cultural relations in a multicultural society. The Foundation is an active member of a high quality international network, and has an access to extensive international know - how and experience.

Partner 3: Inova Consultancy ltd/WiTEC UK, 45A Crescent Road S7 1HL Sheffield South Yorkshire, United Kinkdom

URL: http://www.inovaconsult.com, http://www.witec-eu.net/ e-mail: office@inovaconsult.com

The Inova Consultancy provides a flexible consultancy service that responds to the needs of organizations and individuals internationally in the area of diversity, equal opportunities and entrepreneurship. Inova's team has specialist experience and a proven track record in bid writing and the management of European and national funded projects in these fields. Inova has specialist experience in the development and delivery of programs in the UK and on an international level for women entrepreneurs and women in management. Inova represents WITEC, the European association for Women in SET (Science, Engineering and Technology). Inova has benefited from the knowledge and expertise of more than 20 years of experience in the delivery of gender programs across Europe. Inova's employees and associates combine experience and qualifications in organizational development, psychology, mentoring and coaching in addition to bringing in best practice from across Europe to assist organizations and individuals in the field of personal and business development.

Inova is also a member of the BME Business Forum in Sheffield.

Partner 4: PRO-MED Spolka z ograniczona odpowiedzialnością, Migowo Dolne 16 C, 80952 Gdansk, Poland

URL: http://pro-med.org.pl/ http://blanka.moodle.pl/, http://utw.moodle.pl/ e-mail: anka.grabowska@gmail.com

PRO-MED sp. z o.o. activities on the Polish and international markets have been dated since 1989. PRO-MED sp. $\mathrm{z}$ o.o. main services are the following: installation and maintenance of medical equipment, translations and verifications of technical and medical literature and documentation, adaptation and localization of Web pages, developing and delivery of e-learning, blended learning courses, translation and localization of Polish Language Pack for Learning Management System (BSCW, WebCT, Moodle), taking part in EU projects: Phare (1998-2000), Leonardo da Vinci (1998 2008), Socrates (1998 - 2007), EQUAL (2005-2008), Interreg (2005-2006), Lifelong Learning Programs Grundtvig Partnership and Multilateral (2008-2011). 


\section{Introducing the Best Practice and "Share and Valorize" Approach (UTA Online, e-senior.eu in Action, MindWellness)}

The author of the article is employed in PRO-MED sp. $\mathrm{z}$ o. o. as an e-learning expert. PRO-MED will offer at least 6 different e-workshops in the framework of LLLab project. The proposal is based on the idea "Share and Valorize" described in [3]. First of all the concept of virtual university will be used [4]. In order not "re-inventing the wheel" the best practice example from previous EU projects (e-senior.eu in action [5], Mindwellness [6]) will be offered. Fig. 1 presents the idea "Share and Valorize".

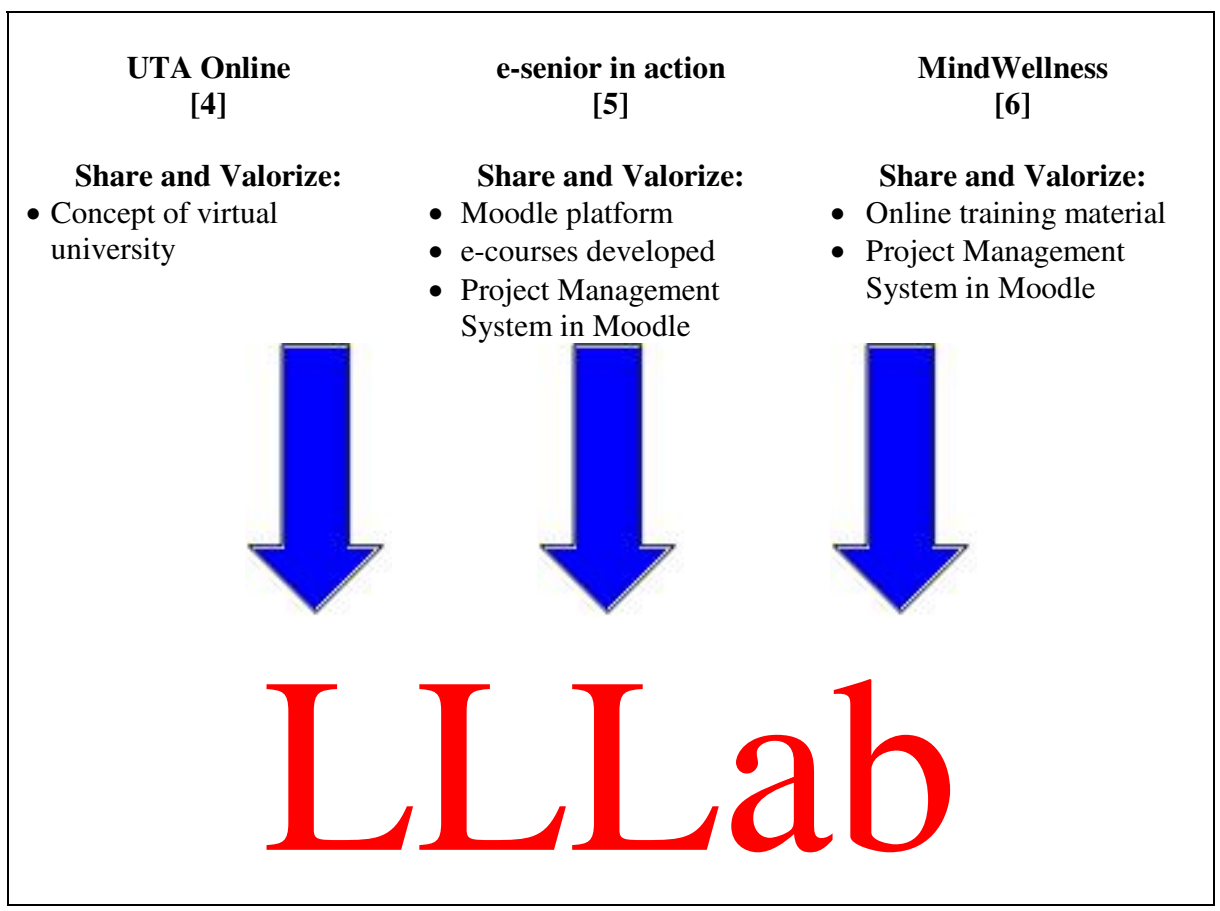

Fig. 1. The concept of "Share and Valorize"

The first good practice is U3A Online [4]. U3A Online is a world-first virtual University of the Third Age delivering online learning via the Internet. Their courses are open to all older people anywhere in the world. They are especially suited to older members of the community who are isolated either geographically, or through physical or social circumstances. All that is needed to study online is access to a computer with an Internet connection - and some basic computing skills. Before enrolling in a U3A Online (U3AOL) course, the user should become a member of U3A Online and receive a free username and password. UTA Online is based on Blackboard Learning Management System which is a commercial solution.

The second good practice is "e-senior in action" project (September 2009- April 2010) [5]. It has an aim to integrate and activate the members of the Seniors' Club at 
Gdansk University of Technology (GUT). In "e-senior in action" computers workshops with elements of e-learning and open-air meetings, where their knowledge and skills gained during e-courses is verified (e.g. Nordic Walking) were offered.

Table 1. "e-senior.eu in action" work plan

\begin{tabular}{|c|c|}
\hline Month & Activities done \\
\hline September 2009 & $\begin{array}{l}\text { Open-air meetings in Czarlina GUT summer camp, meetings at the } \\
\text { Senior's Club - the presentation of ideas and project tasks, additional } \\
\text { recruitment of participants; } \\
\text { IMPROGE - Grundtvig Partnership Programme meeting in Rome - } \\
\text { presenting the idea of e-senior.eu in action project; }\end{array}$ \\
\hline October 2009 & $\begin{array}{l}\text { Design and the implementation of the web site e-senior.eu; } \\
\text { The choice and start up the Learning Management System (LMS); } \\
\text { Workshops at Technical University of Gdansk- registration of LMS } \\
\text { users; } \\
\text { Connecting }+\mathbf{5 5}, \boldsymbol{E u B i A} \text { - Grundtvig Partnership Programs meetings in } \\
\text { Gdansk - presenting the idea of e-senior.eu in action project; }\end{array}$ \\
\hline November 2009 & $\begin{array}{l}\text { Preparation and implementation of e-courses; } \\
\text { Workshops at Gdansk University of Technology; }\end{array}$ \\
\hline December 2009 & $\begin{array}{l}\text { Preparation and implementation of e-courses; } \\
\text { Workshops at Gdansk University of Technology; }\end{array}$ \\
\hline January 2010 & $\begin{array}{l}\text { Testing and using of e-courses; } \\
\text { Workshops at Gdansk University of Technology; }\end{array}$ \\
\hline February 2010 & $\begin{array}{l}\text { Testing and using of e-courses; } \\
\text { Workshops Gdansk University of Technology; }\end{array}$ \\
\hline March 2010 & $\begin{array}{l}\text { Open air meetings and verification of knowledge obtained during } \\
\text { e-learning training; } \\
\text { Workshops at Gdansk University of Technology; } \\
\text { IMPROGE - Grundtvig Partnership Programme meeting in Rome - } \\
\text { presenting the results of e-senior.eu in action project; }\end{array}$ \\
\hline April 2010 & $\begin{array}{l}\text { Open air meetings and verification of knowledge obtained during } \\
\text { e-learning training; } \\
\text { The preparation of project presentation for the national and international } \\
\text { conferences, workshops, meetings } \\
\text { Project evaluation; } \\
\text { Promotion of the project (leaflets, conferences, workshops) ; }\end{array}$ \\
\hline
\end{tabular}

The practical effect of e-courses (ICT, English, Nordic walking) is proved by the participation in Socrates Grundtvig Partnership meetings. During the international meetings, experiences and skills gained in the "e-senior.eu in action" project are presented.

The third good practice is "MindWellness - Improving learning capacities and mental health of elder people" project [6].

Mindwellness is a 2-year international project, funded by the European Union's "Grundtvig" programme.

There are 11 project partners in 9 countries, including relevant specialists in adult education, pedagogues, medical doctors, university researchers, ICT experts and social researchers. 
The project has been developing innovative training material aimed at older people (working or retired) to help them retain mental flexibility.

The outcomes of the project include:

- a national and comparative analysis on the current position of older citizens and learning in higher age;

- a collection of good examples and best practice related to mind developing;

- online training material with exercises on mind developing;

- a handbook on mind developing for older people, providing a theoretical basis for use by trainers and experts.

In LLLab project PRO-MED sp. z o.o. offers Moodle platform which is a free web application that educators can use to create effective online learning sites. The usefulness of the platform for a seniors' audience was tested under "e-senior.eu in action" project. In the period September 2009 and April 2010 several e-courses for seniors were developed and delivered: e-senior - Nordic Walking, e-seniors English Club, e-seniors Fitness Club, e-seniors Photo Club.

\section{Summary}

The proposed workshops are located in Moodle platform (Fig. 2). The same platform is also used for the LLLab project management. Fig. 3 shows the timetable of LLLab project regarding workshops delivery and Grundtvig Partnership meetings.

Up till now PRO-MED sp. $\mathrm{z}$ o.o. delivered the following workshops:

1. e-cards for Christmas

2. e-cards for Easter

21 i 2 Warsztat pocztówkowy, 12/2009-04/2010

Przygotowanie: Anka G., Ela P., Tomek K.

Prowadzenie: Anka, Ela, Ewa, Kacper,Tomek, Wojtek

茈 Warsztat pocztówkowy - forum instruktorów

1 Warsztat - pocztówki

Warsztaty pocztówkowe - Studia Podyplomowe WETI

Jak zrobić wielkanocną kartkę w programie PAINT

?] Warsztat pocztówkowy - Wielkanoc 2010 (26/03)

33 Warsztat - Nordic walking, 1/2010- 4/2010

Przygotowanie: Anka G., Ela P.

Prowadzenie: Zbyszek Ch.

?] Nordic walking

Nordic walking in Jelitkowo, 24/04/2010

44 Warsztat - Telefony komórkowe dla seniorów, 5/2010

Przygotowanie: Tomek K., Piotr G.

Prowadzenie: Piotr G.

Fig. 2. Example e-workshops offered in LLLab project 


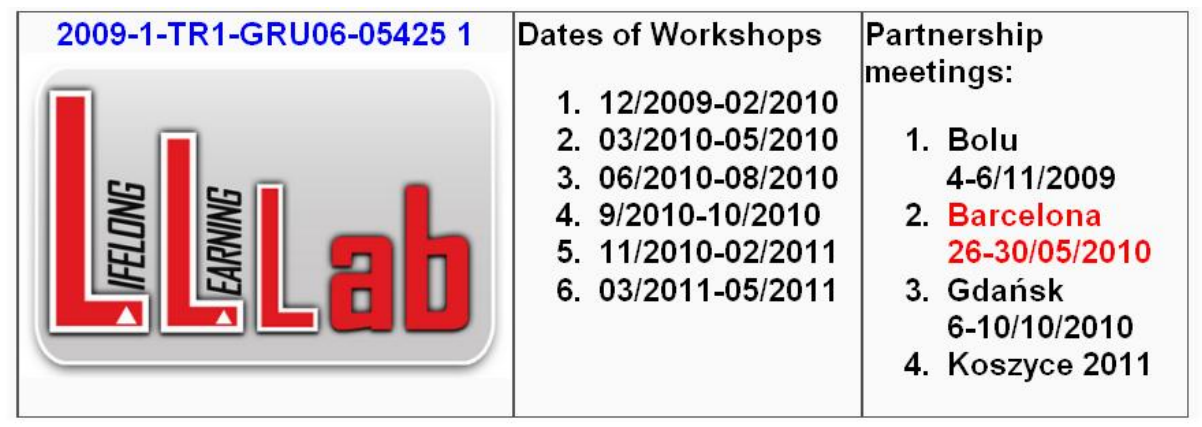

Fig. 3. Example information about LLLab project located in Moodle

3. Nordic walking

4. Mobiles phones for seniors

The idea of establishing the online e-senior Magazine was born in 2008 during the EDEN Conference in Lisbon. The most interesting projects' events and achievements are documented there as essays [10].

\section{References}

1. European Commission Education \& Training, http://ec.europa.eu/ education/lifelong-learning-programme/doc86_en.htm/

2. LifeLong Learning for Active Citizenship and Capacity Building - LLLab, http: / /www.lilelab.com/

3. Grabowska, A.: Valorisation of European Projects Results. In: Book of Abstracts EDEN Annual Conference 2007, New Learning 2.0? Naples, p. 182 (2007)

4. A Virtual University of Third Age, UTW Online, http: / /www3.griffith.edu.au/03/u3a/

5. e-senior.eu in action, http://e-senior.eu/, http://utw.moodle.pl/

6. MindWellness, Improving learning capacities and mental healt of elder people, http: / / www.mindwellness.eu/

7. Blackboard home, http: / /www.blackboard.com/

8. Moodle community, http://moodle.org/

9. Creative Commons, http: / / creativecommons .org/

10. e-senior online magazine, http://magazinefactory.edu.fi/magazines/e_senior/ 